\title{
The Cultivation and Ornamental Uses of Persimmon in Piedmontese Gardens
}

P. Gullino ${ }^{\text {a }}$, M. Devecchi and F. Larcher

Department of Agronomy, Forest, and Land Management

Faculty of Agronomy

University of Turin - Via Leonardo da Vinci n. 44

10095 Grugliasco (TO)

Italy

Keywords: Diospyros kaki, private garden, Piedmont, ornamental plant, landscape design, germplasm

\begin{abstract}
In Italy, during the XIX century, the use of Diospyros kaki L. was mainly linked to its productivity. Indeed, in those years different cultivars were commonly sold on the Italian market. Few specimens could be found in botanical gardens (also in Turin) labelled as 'botanical rarities'. In the XIX century these species were not considered as a garden plant instead of more appreciated classic ornamental conifers and broad-leaved plants. However, in Piedmont some isolated plants were present. In the XX century, with the decrease of the English landscape garden style, widespread in Europe during the previous century, some landscape designers, such as Russell Page, introduced orchards in the garden. Then, many landscape architects decided to introduce fruit trees as structural features of the gardens itself. The presence of persimmon in gardens was to link its productivity with the opportunity of using ornamental species that previously were not practically used. At present, in some Piedmontese gardens, rows of Diospyros kaki L. were used to create long alleys or as isolated plants as eye-catchers.
\end{abstract}

\section{INTRODUCTION}

Since the VIII century in Asia, the persimmon was appreciated in China, Korea and Japan. For centuries different species were cultivated in these countries and now more than two thousand different cultivars exist (Ragazzini, 1983).

In Europe the more cultivated species are Diospyros kaki L., D. lotus and D. virginiana (Aloj et al., 1982). The persimmon was imported in the European countries of the Mediterranean Basin hundreds of years ago (Bellini and Giordani, 2003). In particular $D$. lotus was introduced from Asia in the 1550 s and D. virginiana in the 1760 s from Northern America (Maniero, 2000). D. lotus, also called 'false lotus tree' was cultivated in many historical gardens. The Grand Duke Cosimo I de Medici and his wife Eleonora of Toledo designed in 1550 the vast Boboli Gardens and planted exotic trees such as the Indian banyan and the 'false lotus'. Cosimo I also had an orchard of dwarf fruit trees and in 1563 established a nursery for citrus fruits (Hobhouse, 1992). In Tuscany, in productive gardens also many of the local plants were cultivated such as olives, vines and cypresses.

During the XVIII century, mainly English and German plant hunters travelled through eastern countries and discovered many flowers, shrubs and exotic trees as $D$. kaki.

The persimmon was mostly appreciated for the quality of its hard wood, so called ebony, that represents one of the most valuable wood employed in cabinet works for ebon. The difficulty to value the fruit's ripening was probably one of the reasons why $D$. kaki was not at first much considered in Europe. However for the growing, the sweet and the agreeable taste of its fruits soon became very interesting.

In Italy the persimmon was introduced in 1803 and cultivated and planted in

a paola.gullino@unito.it 
gardens for its ornamental and peculiar features like the colour and the shape of the fruits. The famous botanist Angiolo Pucci wrote that in 1871 the first D. kaki was planted in Florence, in the Boboli Gardens and during the following years its orange fruits were shown for the first time during a conference in December of 1876 (Pucci, 1890).

Only at the end of the XIX century the propagation material of persimmon was introduced in Southern Europe. In this period in Italy the use of Diospyros kaki L. was mainly linked to its productivity, and nurserymen started growing persimmon in the early XX century (Bellini, 1982).

This study proposed to investigate the presence of persimmons in private gardens of Piedmont (Northern Italy) and their ornamental uses.

\section{MATERIALS AND METHODS}

While several public historical gardens, located in different districts of Piedmont were studied in the past, numerous private gardens are still unknown. A research was recently performed to understand the style of the gardens, the work of landscape architects, the history of the sites with particular emphasis on the botanical richness (Accati, 2007). A plant that represented a botanical resource as ornamental tree is Dyospiros kaki because its uses changed. The study had as a purpose in fact, to investigate in Piedmontese gardens the presence of persimmon as ornamental plant.

The investigation analysed and selected 121 private gardens of Piedmont located in different districts (Fig. 1). The gardens are historical and contemporary parks and they were designed by Italian and abroad landscape architects or by the same house owners.

In this work a deep bibliographic research was conducted but few information was found in ancient documents and catalogues kept in public and private archives and a small number of old trees Diospyros kaki were found collected in historical Piedmontese gardens. The specimens of Diospyros spp. commercialized during the XIX and XX centuries were collected into botanical gardens (also in Turin) and were labelled as 'botanical rarities'.

The goal of the study was to analyse the botanical species present in private gardens. For each garden was individuated the more important plants and their ornamental uses.

\section{RESULTS AND DISCUSSION}

This study showed that only in few Piedmontese gardens some isolated plants of Diospyros kaki were still present, while the other species are absent. In the past different situations characterized and modified the gardens in Tuscany where monumental trees of persimmon are actually present. In Piedmont, during the second half of the XIX century D. kaki was not considered as a garden plant instead of more appreciated classic ornamental conifers and broad-leaved plants. During the English landscape garden style in fact, the persimmon was considered only as a fruit plant and in particular for its productivity. Later, only in the second half of XX century in many Piedmontese gardens new species were planted. A very important English landscape designer, Russell Page, introduced the orchards in the garden for the first time. In his book 'The Education of a Gardener' he explained the importance of the double attitude of the plants. His new and surprising idea was to create a productive and ornamental garden in the same time (Page, 1962). After that many landscape architects decided to introduce fruit trees as structural features of the gardens itself. Recently, in many Piedmontese gardens D. kaki was considered as an important ornamental plant.

In the gardens studied only 17 showed plants of $D$. kaki. The persimmons have different interesting ornamental uses (Table 1).

In many of the gardens studied in Piedmont (6) ornamental persimmons were planted as individual and isolated specimens (single) in the centre of the garden as eyecatchers. In other parks (8) Diospyros kaki was introduced with other fruit trees to create an ornamental orchard as a structural feature of the gardens itself. In "Villa il Frescot" all the fruit trees including persimmon were delimitated by hedges of Buxus sempervirens. In 
"Masseria del Corno" close to Lake of Orta also arbours of Vitis vinifera were used to enclose an ornamental orchard. In "Vigna La Marchesa" different fruit trees as lemon, pear, apple, cherry and peach trees composed the productive garden with other beautiful flowers. In the greenhouse near the house vegetables are grown.

In other gardens persimmons are located in the yard to showcase their fall and beautiful foliage, to create property bourdaries or long spectacular alleys (Fig. 2). For example, Russell Page in 1958 planted individual persimmon plants in "Villa d'Agliè". Then, Paolo Pejrone a contemporary landscape architect, planted in the centre of the gardens of "Villa La Bossola" a single persimmon tree (Fig. 3). The English author designed the garden of "Villar Perosa" (1955) near Turin and delimited by persimmons, apple and pear trees all the alleys that connect the park. The artist Carlo Maria Maggia, that designed the garden "Castello di Maiolo", used many persimmons in different ways. Single plants in fact near the house are planted as individuals, while others located on the terrace create a productive wood (Fig. 4), while others create ornamental productive orchards.

\section{CONCLUSIONS}

Since ancient times, many exotic plants were collected and cultivated into private gardens of Piedmont and now represent an important botanic source of germplasm.

At present though, the interest for persimmon species that can be used for ornamental and landscape purposes is still not very common. In few private gardens of Piedmont persimmon plants are still present and they were introduced recently.

Some ornamental varieties of Diospyros have a potential role for their peculiar characteristics such as the thick and beautiful foliage, the sculptural and elegant habitus, and the ornamental fruits, that remain on the trees after leaf fall until January (Ragazzini, 1983). The importance of the presence of plants, previously not used in garden architecture such as the persimmon, was to link their productivity with the opportunity of their use in ornamental design. These characteristics give them high ornamental value, especially in temperate climate areas. The development of a successful Diospyros ornamental nursery industry and the exchange of genetic material found in historical gardens would be a contribution to the flow of genotypes showing peculiar and original features.

\section{Literature Cited}

Accati, E. 2007. Arte e Natura 120 Giardini Privati del Piemonte. Daniela Piazza Editore.

Aloj, B., Alvisi, F., Bellini, E., Gorini, F., Monzini, A., Nicotra, A., Noviello, C. and Viggiani G. 1982. Il Kaki. Frutticoltura anni 80, Ramo editoriale degli agricoltori.

Bellini, E. 1982. Monografia delle principali cultivar di kaki introdotte in Italia. Regione Emilia-Romagna, Firenze.

Bellini, E. and Giordani, E. 2003. Germoplasm Conservation of Persimmon in Europe. Acta Hort. 601:37-46.

Hobhouse, P. 1992. Plants in Garden History. Pavillons Books, London.

Maniero, F. 2000. Fitocronologia d'Italia. Ed. Leo S. Olschki.

Ragazzini, D. 1983. La coltivazione del kaki. Edagricole.

Page, R. 1962. L'educazione di un giardiniere. Ed. Allemandi, Torino.

Pucci, A. 1890. Il Diospyros kaki. Bollettino Società Toscana di Orticoltura. 


\section{Tables}

Table 1. List of piedmontese gardens where are still present $D$. kaki used with different attitude.

\begin{tabular}{|c|c|c|c|c|}
\hline Name of the Garden & Projector & Location & $\begin{array}{l}\text { Date of } \\
\text { project }\end{array}$ & $\begin{array}{c}\text { Ornamental use of } \\
\text { Diospyros kaki }\end{array}$ \\
\hline 1. Castello di Maiolo & Carlo Maggia & Marentino (To) & 1993 & Single/Orchard/Wood \\
\hline $\begin{array}{l}\text { 2. Castello di Rive } \\
\text { Vercellesi }\end{array}$ & Home owner & Rive Vercellesi (Vc) & 1980 & Orchard \\
\hline 3. Castello di Solere & Home owner & Savigliano (Cn) & 1976 & Single \\
\hline 4. Giardino Bramafan & Paolo Pejrone & Revello (Cn) & 1995 & Wood \\
\hline $\begin{array}{l}\text { 5. Giardino di Carla } \\
\text { Bellora }\end{array}$ & Homeowner & Agrate Conturbia (No) & 1988 & Single \\
\hline $\begin{array}{l}\text { 6. Giardino segreto } \\
\text { alle Moline di Vico }\end{array}$ & Home owner & Mondovì (Cn) & 1982 & Orchard \\
\hline 7. Il Becchio & Anna Patrucco & Casale Monferrato (Al) & 2006 & Single \\
\hline $\begin{array}{l}\text { 8. Il giardino } \\
\text { riscoperto }\end{array}$ & Elena Balsari & Val Sesia $(\mathrm{Vc})$ & 1994 & Orchard \\
\hline 9. Masseria del Corno & Elena Balsari & Lake of Orta (No) & 1993 & Orchard \\
\hline 10. Vigna La Marchesa & Home owner & Turin & & Orchard \\
\hline 11. Villa I Frescot & Home owner & Turin & 1970 & Orchard \\
\hline 12. Villa d'Agliè & Russell Page & Turin & 1958 & Single \\
\hline 13. Villa La Bossola & Paolo Pejrone & Turin & 1998 & Single \\
\hline 14. Villa Oddone & Home owner & $\begin{array}{c}\text { Baldissero Canavese } \\
\text { (To) }\end{array}$ & 1956 & Orchard \\
\hline 15. Villa Ottolenghi & Pietro Porcinai & Acqui Terme (Al) & 1955 & Wood \\
\hline $\begin{array}{l}\text { 16. Villa Viridissima } \\
\text { Quies }\end{array}$ & Home owner & Turin & 1988 & Alley \\
\hline 17. Villar Perosa & Russell Page & Villar Perosa (To) & 1955 & Alley \\
\hline
\end{tabular}




\section{Figures}

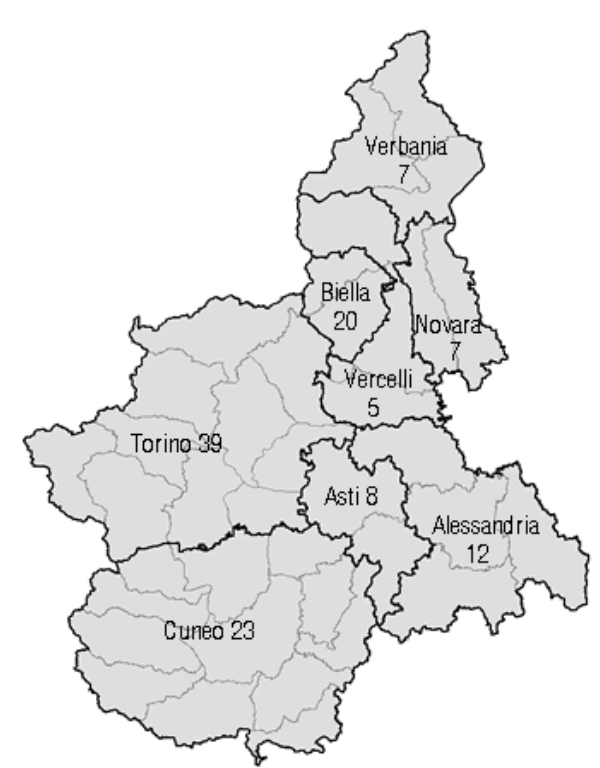

Fig.1. Number of private gardens studied in Piedmont for each district.

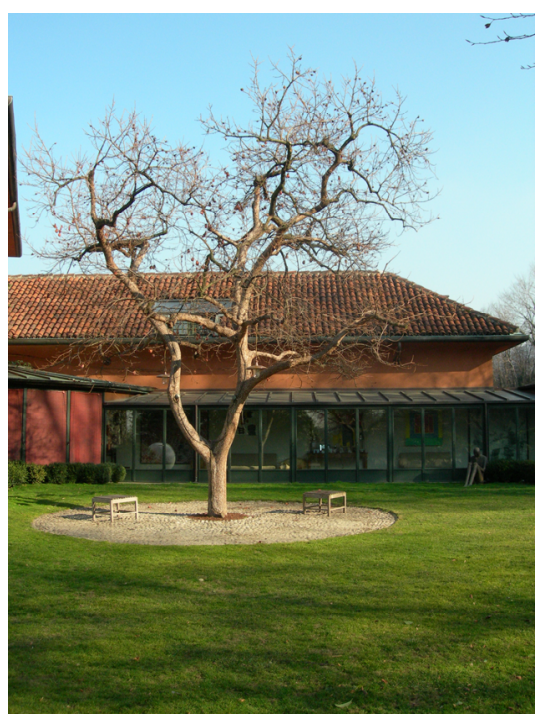

Fig. 3. A sculptural persimmon planted in the centre of "Villa La Bossola" (To) garden.

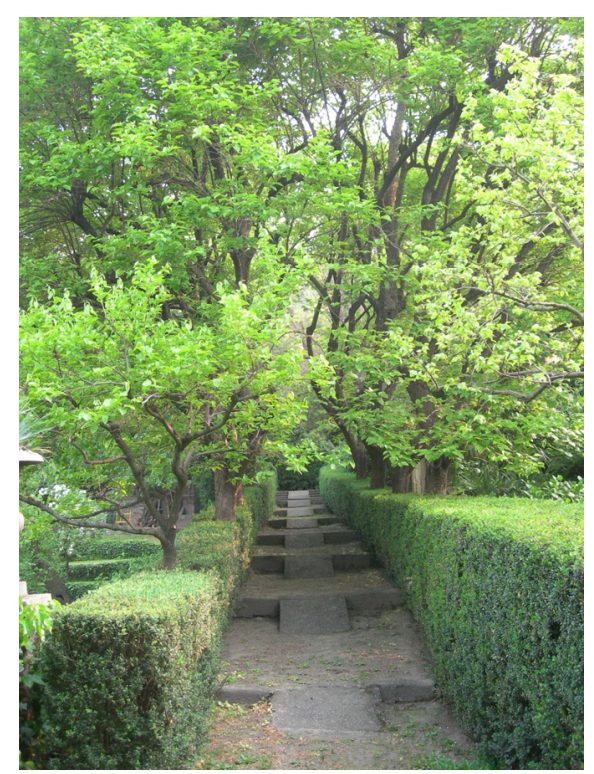

Fig. 2. Plants of persimmon along a shadowy alley in "Villa Viridissima Quies" (To).

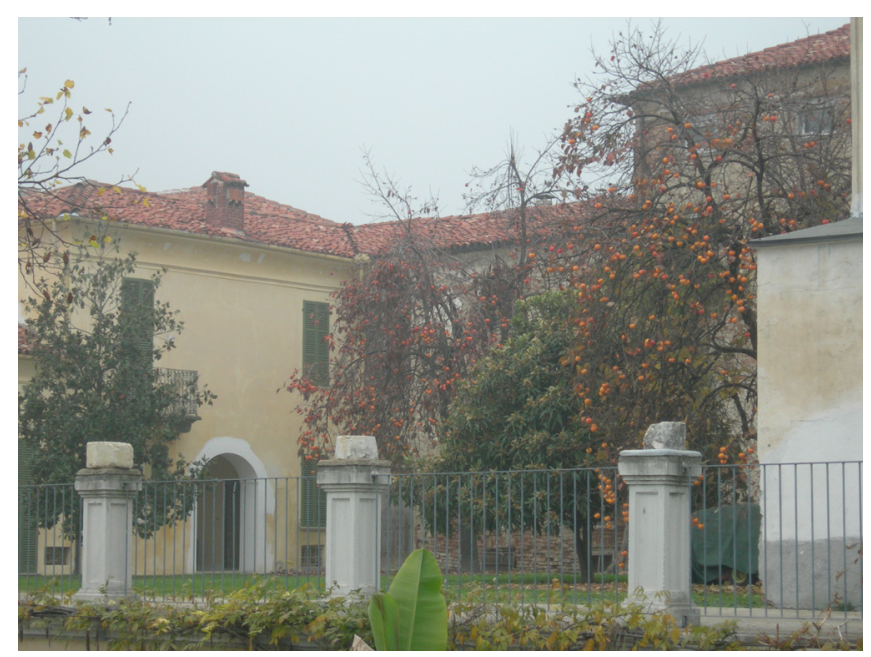

Fig. 4. Persimmon's plants creating a little productive wood on the terrace of "Castello di Maiolo" (To). 
